Check for updates

Cite this: RSC Adv., 2017, 7, 46388

Received 10th July 2017

Accepted 12th September 2017

DOI: 10.1039/c7ra07578b

rsc.li/rsc-advances

\section{Properties of a new renewable sesame protein adhesive modified by urea in the absence and presence of zinc oxide}

\author{
Xiaobo Wei, (D) Xuede Wang, ${ }^{*}$ Yaoran Li and Yuxiang Ma
}

Sesame protein (SP) is a new renewable resource for wood adhesives because of its brilliant performance, which is non-toxic and harmless to human health during the process of using plywood. This study was focused on the application of sesame protein to produce wood adhesive via urea and zinc oxide $(\mathrm{ZnO})$ modification. The $\mathrm{pH}$ value, solid content, apparent viscosity, bonding strength, infrared spectra, thermal stability, and fracture surface of urea-modified sesame protein adhesives in the absence of ZnO (USP) and in the presence of $\mathrm{ZnO}$ (ZUSP) were investigated in detail. The results suggested that the $\mathrm{pH}$ value and solid content of the ZUSP adhesives increased, whereas the apparent viscosity of the ZUSP adhesives showed an increasing trend when $\mathrm{ZnO}$ was introduced. The wet shear strength of the ZUSP adhesives improved remarkably, which achieved the required value for interior use ( $\geq 0.70 \mathrm{MPa})$, which was in accordance with the China National Standard. The infrared spectra (FTIR) indicated that the chelation reaction occurred between the USP adhesive and ZnO that improved the water resistance. The thermal stability of the ZUSP adhesives was better than that of the USP adhesive, as confirmed by the thermogravimetric analysis (TGA). After ZnO was introduced, the fracture surface of the ZUSP adhesives became more compact as compared to that of the USP adhesive, as confirmed by scanning electron microscopy. The ZUSP adhesive is a favorable potential candidate as a green-adhesive for the plywood industry, which will promote the utilization of sesame protein.

\section{Introduction}

Wood adhesives play a predominant role in the practical production of plywood. Currently, formaldehyde-based adhesives such as urea- (UF), phenol- (PF), and melamineformaldehyde (MF) resins play a prominent part in the wood adhesives industry. ${ }^{1}$ These resins have huge advantages such as low price and viscosity, high bonding strength, and great water resistance, which are in fundamental demand for wood adhesives; ${ }^{2}$ however, problems, such as lack of renewability and formaldehyde emission, which are harmful to the environment and human health, associated with these resins have attracted serious concern from researchers. Therefore, these issues have generated an urgent requirement of new renewable and environmentally friendly adhesives for wood. ${ }^{3,4}$

Plant protein-based adhesives are renewable, substantial and low-cost, and this kind of wood adhesives have received increasing attention by researchers to replace the formaldehyde-based adhesives. Many researchers have investigated plant protein-based adhesives such as soy protein-based adhesive, peanut protein-based adhesive, and cotton protein-based

College of Food Science and Technology, Henan University of Technology, Zhengzhou 450001, China. E-mail: weixiaobo1992@qq.com; wangxuede1962@126.com; Fax: +86-371-67758025; Tel: +86-371-67758025 adhesive. ${ }^{5-11}$ However, the low-water resistance and solid content of the plant protein-based adhesives have limited their application in the wood adhesive industry. ${ }^{12}$ It is essential to improve water resistance of plant protein-based adhesives to expand their application. Many chemical methods have been used to modify plant protein-based adhesives to enhance the water resistance, which can be classified into three categories: denaturing agent modification, protein molecular modification, and protein and resin blend modification. ${ }^{13-19}$

Currently, China has the largest global sesame production industry in the world. Sesame meal is a by-product of the extraction of sesame oil in sesame seeds, which is primarily used as a livestock feed and fertilizer, but this does not take full advantage of the sesame protein. Therefore, the issue of sesame protein utilization has received attention from researchers. The proteins in sesame seeds are mainly composed of globulins $(67.3 \%)$, albumins (8.6\%), glutelins (6.9\%), and prolamins $(1.4 \%) .{ }^{20}$ Many chemical reactions can take place in the functional groups, such as carboxyl $(-\mathrm{COOH})$, hydroxyl $(-\mathrm{OH})$, amino $\left(-\mathrm{NH}_{2}\right)$, and thiol $(-\mathrm{SH})$ groups, of the sesame protein. Therefore, sesame protein can be easily modified to change the physical properties of sesame protein-based adhesives.

Urea has been used in many fields because of its peculiar properties, which acts as a structure breaker and maker for many proteins (both fibrous and globular), micellar aggregated 
systems consisting of many synthetic tanning (syntans), and vegetable materials, surfactants, polymers, peptides, and emulsions, and its properties depend on many conditions such as temperature and nature of the added substrates. ${ }^{21-25}$ For plant protein adhesives, urea was widely used as a denaturing agent for modified protein because of its useful properties, which could break the structure of sesame protein and expose the inner functional groups such as $-\mathrm{NH}_{2},-\mathrm{COOH}$, and $-\mathrm{OH} .{ }^{26}$ However, it was difficult for the plant protein-based adhesive modified by only this method to meet the requirement of interior use of plywood, and it could not achieve high water resistance. The bivalent metals easily form coordinated bonds, which are features of chelates. The coordinated bond, also called a complex bond, is composed of a metal and a ligand aligned in a way that the available electrons from the coordination atoms are in close proximity to those from the metal. ${ }^{27}$ Zinc oxide $(\mathrm{ZnO})$ could be used to react with $-\mathrm{NH}_{2}$ of sesame protein by chelation, which could remarkably enhance the properties, such as bonding strength and water resistance, of an adhesive. Therefore, urea and zinc oxide modification could be an impactful way to prepare a sesame protein-based adhesive.

The objective of this research was to expand the utilization of sesame protein and improve the bonding strength and water resistance by modifying sesame protein with urea and zinc oxide. In this study, the physicochemical properties, including the solid content and $\mathrm{pH}$ value, surface structure of cured adhesives, functional groups, thermal stability, and rheological properties, of modified sesame protein-based adhesives were analyzed. Herein, a three-ply plywood was fabricated with a modified adhesive, and its dry shear strength and water resistance were tested.

\section{Materials and methods}

\subsection{Materials}

Dehulled sesame was purchased from Kangbo Huixin Oil Company (Henan, China), which was obtained by wet decortication from sesame seeds. Urea (Luoyang Reagent Company, Henan, China) and zinc oxide (ZnO, Xilong Chemical Industry Company, Fujian, China) were analytical-grade reagents. Poplar veneer $(400 \times 400 \times 2.1 \mathrm{~mm}, 10 \%$ moisture content $)$ was provided by the Zhengzhou Bio Biologic Materials Company (Henan, China).

\subsection{Preparation of the sesame protein}

2.2.1 Defatting of the dehulled sesame. Dehulled sesame was pressed by a hydraulic oil press at room temperature and milled into flours ( $\geq 40 \mathrm{mesh}$ ). The dehulled sesame flours were defatted by petroleum ether via soxhlet extraction for $8 \mathrm{~h}$ at $50{ }^{\circ} \mathrm{C}$ and dried in an oven for $2 \mathrm{~h}$ at $50{ }^{\circ} \mathrm{C}$. The defatted dehulled sesame flours were used for protein extraction.

2.2.2 Extraction of sesame protein. Sesame protein was extracted using an alkali method. ${ }^{28}$ The defatted dehulled sesame flours were dispersed in deionized water (ratio $1: 20$ $\mathrm{w} / \mathrm{v}$ ), the $\mathrm{pH}$ value was adjusted to 10 using $1 \mathrm{M} \mathrm{NaOH}$, and stirring was carried out for $3 \mathrm{~h}$ at $50{ }^{\circ} \mathrm{C}$. The slurry was centrifuged at $4000 \mathrm{rpm}$ for $10 \mathrm{~min}$. The $\mathrm{pH}$ value of the supernatant was adjusted to 4.2 using $1 \mathrm{M} \mathrm{HCl}$, and stirring was carried out for $5 \mathrm{~min}$ at $50{ }^{\circ} \mathrm{C}$. The suspension was preserved at $4{ }^{\circ} \mathrm{C}$ for $20 \mathrm{~min}$ and then centrifuged at $4000 \mathrm{rpm}$ for $10 \mathrm{~min}$. The precipitates were obtained by washing twice with deionized water and adjusting the pH valur to 7.0 using $1 \mathrm{M} \mathrm{NaOH}$ and then freeze-dried. The sesame protein was milled into a powder using a ball mill. The composition of the sesame protein was analyzed according to the China National Standards $(84.1 \%$ sesame protein, $3.5 \%$ moisture, $3.5 \%$ ash, $4.9 \%$ fat, $0.11 \%$ fiber, $0.08 \%$ oxalic acid, and $2.8 \%$ polysaccharide).

\subsection{Preparation of the sesame protein adhesive}

For the sesame protein adhesives, sesame protein (10 g) was added to the urea solution $\left(80 \mathrm{~mL}, 3 \mathrm{~mol} \mathrm{~L}^{-1}\right)$, and the mixture was stirred for $20 \mathrm{~min}$ at $25^{\circ} \mathrm{C}$. Zinc oxide $(0,4,8,12,16$, and $20 \%$ based on the mass of sesame protein) was added to the sesame protein adhesive, and the mixture was stirred for $220 \mathrm{~min}$ at $25^{\circ} \mathrm{C}$ to obtain a urea-modified sesame protein adhesive (USP) and ZnO-modified sesame protein adhesive containing urea (ZUSP) (4, 8, 12, 16, and $20 \%$ ZUSP).

\subsection{Solid content test}

The solid content of the adhesive samples was tested by an oven-drying method. Approximately $3 \mathrm{~g}$ (weight $\beta$ ) of the adhesive was placed in an oven and dried at $105^{\circ} \mathrm{C}$ for several hours until a constant weight (weight $\alpha$ ) was achieved. The solid content value was calculated by the following eqn (1). Reported values are the average of the three parallels for each adhesive.

$$
\text { Solid content }(\%)=\frac{\alpha(\mathrm{g})}{\beta(\mathrm{g})} \times 100 \%
$$

\section{5 pH test}

The $\mathrm{pH}$ value of the adhesive was measured by a $\mathrm{pH}$ meter. The $\mathrm{pH}$ buffers ( $\mathrm{pH}$ value 4.00, 6.86, and 9.18) were selected according to the $\mathrm{pH}$ of the adhesive sample. The $\mathrm{pH}$ of the adhesive was tested by the electrode after calibration. The average $\mathrm{pH}$ value was calculated from three parallel samples.

\subsection{Apparent viscosity test}

The apparent viscosity of the adhesive samples was determined using a RS-6000 rheometer (Thermo Fisher scientific corporation, Waltham, MA) with a parallel plate fixture (20 $\mathrm{mm}$ diameter). The distance between the cone and plate was set to $1 \mathrm{~mm}$ for all tests. The experiments were conducted under a steady shear flow at $25{ }^{\circ} \mathrm{C}$. The shear rates ranged from 0.01 to $100 \mathrm{~s}^{-1}$ in $10 \mathrm{~s}^{-1}$ increments. An average of three parallels was recorded as the value of the apparent viscosity of a specimen.

\subsection{Preparation of a three-ply plywood}

Three-ply plywood samples were prepared under the following conditions: $240 \mathrm{~g} \mathrm{~m}^{-2}$ glue spreading for a single surface, $130{ }^{\circ} \mathrm{C}$ hot pressing temperature, 1.3 MPa hot pressing pressure, and $10 \mathrm{~min}$ hot pressing time. The plywood samples were placed under ambient conditions for $12 \mathrm{~h}$ after hot pressing. 


\subsection{Bonding strength test}

The dry shear strength and the water resistance (wet shear strength, Type II plywood, $\geq 0.70 \mathrm{MPa}$ ) of the plywood were tested according to the China National Standard GB/T 9846.3-2004. Herein, twelve plywood specimens $(100 \times 25 \mathrm{~mm})$ cut from two plywood panels were immersed in water at $63{ }^{\circ} \mathrm{C}$ for $3 \mathrm{~h}$ and then placed under ambient conditions for $10 \mathrm{~min}$ before wet shear strength testing. The dry shear strength of the twelve plywood specimens was directly measured without the soaking treatment. The bonding strength of the plywood specimens was determined using a mechanical testing machine (CMT6203, Xin San Si Materials Company, Shenzhen, China) operating at a speed of $5.0 \mathrm{~mm} \mathrm{~min}{ }^{-1}$. The force $\mathrm{N}$ required to break the glued area was determined. The bonding strength was calculated from eqn (2). The reported bonding strength data were the average of the twelve parallels for each plywood specimen.

$$
\text { Bonding strength }(\mathrm{MPa})=\frac{\text { tension force }(\mathrm{N})}{\text { gluing area }\left(\mathrm{m}^{2}\right)}
$$

\subsection{Fourier transform infrared (FTIR) spectroscopy test}

The adhesive samples were cured in an oven at $120{ }^{\circ} \mathrm{C}$ until an invariable weight was achieved and milled into a powder. The FTIR spectra of the cured adhesive samples were obtained using a Nicolet 6700 spectrometer (Thermo Nicolet Corporation, Madison, WI) in the range from 500 to $4000 \mathrm{~cm}^{-1}$ and scanned 32 times at a $8 \mathrm{~cm}^{-1}$ resolution.

\subsection{Thermogravimetric (TG) measurement}

The adhesive samples were cured in an oven at $120{ }^{\circ} \mathrm{C}$ until an invariable weight was achieved and milled into a powder. The thermal stabilities of the cured adhesive samples were analyzed by a TGA instrument (TA Q50, Waters Company, USA). Approximately $5 \mathrm{mg}$ of the cured adhesive samples was loaded in the pan and heated from 40 to $600{ }^{\circ} \mathrm{C}$ at a rate of $10{ }^{\circ} \mathrm{C} \mathrm{min}^{-1}$ under a nitrogen environment.

\subsection{Scanning electron microscopy (SEM) test}

The adhesive samples were cured in an oven at $120{ }^{\circ} \mathrm{C}$ until an invariable weight was achieved. The surface structure of the cured adhesive samples was observed using a QUANTA FEG 250 scanning electron microscope (FEI Company, Hillsboro, USA). The surface was sputter coated with gold prior to examining it using a microscope.

\section{Results and discussion}

\subsection{Solid content and $\mathrm{pH}$ value of the sesame protein-based adhesives}

Solid content is a fundamental physical parameter for a wood adhesive that influences the adhesive performance during the hot-pressing process. In general, a lower solid content in the adhesive indicates that the larger water content needs to be removed from the adhesive, which has a detrimental effect on the

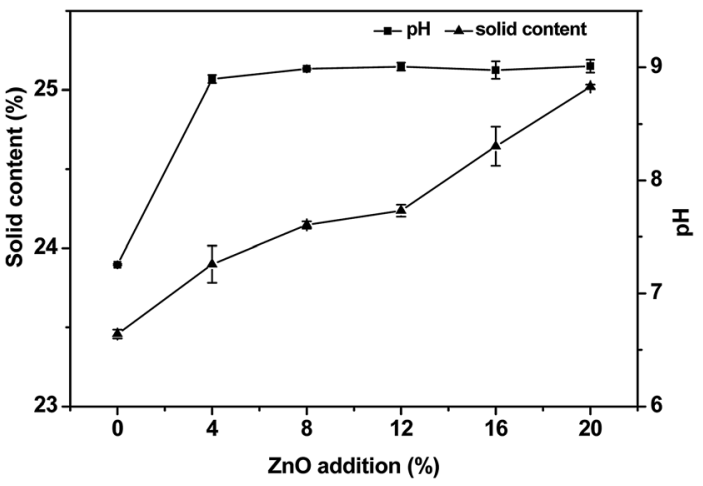

Fig. 1 The solid content and $\mathrm{pH}$ value of the USP/ZUSP adhesives.

hot-pressing process. ${ }^{29}$ However, the exorbitant solid content of the adhesive results in a more difficultly in the coating procedure where the adhesive cannot be well-distributed; this causes a rapid decrease in the water resistance of the adhesive. The average value of the solid content of USP/ZUSP adhesives was calculated from three parallel samples and is shown in Fig. 1. The solid content of the sesame protein adhesives increased gradually from $23.46 \%$ to $25.02 \%$ when the $\mathrm{ZnO}$ content increased from 0 to $20 \%$. This behavior was attributed to one reason that more addition of $\mathrm{ZnO}$ in ZUSP adhesives led to a high solid content.

The $\mathrm{pH}$ of the protein adhesive is important for the production process of plywood, which can easily change the color of the wood veneer in the hot-pressing process. The $\mathrm{pH}$ value of the USP/ZUSP adhesives is shown in Fig. 1. The $\mathrm{pH}$ value of the USP adhesive was 7.26. After introducing $\mathrm{ZnO}$, the $\mathrm{pH}$ value of the ZUSP adhesives maintained at around 9. $\mathrm{ZnO}$ is an alkaline substance, and the $\mathrm{pH}$ value increases when the addition amount of $\mathrm{ZnO}$ is increased from 4 to $20 \%$.

\subsection{Apparent viscosity measurement}

The apparent viscosity of the USP/ZUSP adhesives is shown in Fig. 2, and the initial viscosity of the USP/ZUSP adhesives is presented in Table 1 . With the shear rate increasing from 0.01 to $100 \mathrm{~s}^{-1}$, the apparent viscosity of the USP/ZUSP adhesives decreased. This phenomenon indicated that the USP/ZUSP

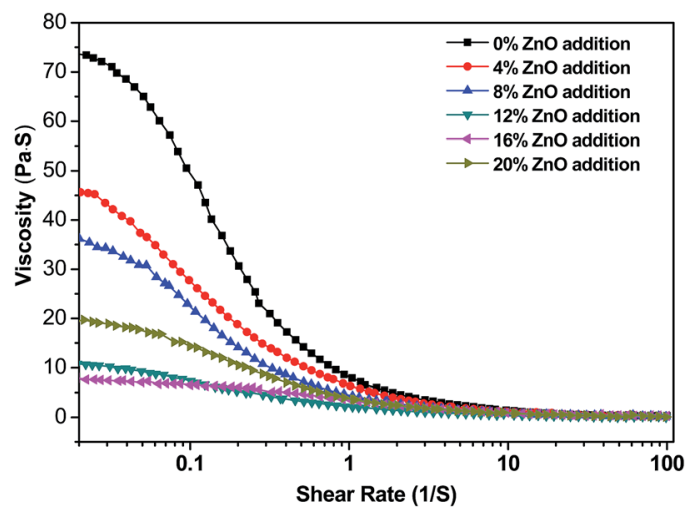

Fig. 2 Apparent viscosity of the USP/ZUSP adhesives. 
Table 1 The initial viscosity of the USP/ZUSP adhesive

\begin{tabular}{lllllll}
\hline ZnO addition (\%) & 0 & 4 & 8 & 12 & 16 & 20
\end{tabular}
Initial viscosity $\quad 71560 \quad 45730 \quad 36950 \quad 11200 \quad 8520 \quad 20120$ (mPa s)

adhesives belonged to shear thinning fluid. When the addition amount of $\mathrm{ZnO}$ was increased from 0 to $16 \%$, the initial viscosity of the ZUSP adhesives decreased from 71560 to $8520 \mathrm{mPa}$. This behavior was due to the following reasons: urea destroyed the globular structure of the sesame protein into small molecular chain protein and led to high viscosity; the chelation reaction between $\mathrm{ZnO}$ and the small molecular chain protein, which formed a regular structure, decreased the viscosity of the ZUSP adhesives; and the salting-in occurred with a low concentration of $\mathrm{ZnO}$ decreased the viscosity of the ZUSP adhesives with the increase in the addition amount of $\mathrm{ZnO}$ addition from 0 to $16 \%$. Moreover, the size of the ZUSP adhesives gradually decreased with the increase in the $\mathrm{ZnO}$ addition amount from 0 to $16 \%$ that was observed in SEM (Fig. 7). However, when the $\mathrm{ZnO}$ addition amount was increased to $20 \%$, the viscosity of the ZUSP adhesive increased to $20120 \mathrm{mPa}$. This result showed that the chelation reaction between $\mathrm{ZnO}$ and protein was saturated, and the viscosity was increased with more $\mathrm{ZnO}$ addition. However, the adhesive with a high viscosity would decrease the flowability; this would cause more difficultly in the coating process. ${ }^{2}$ Therefore, the addition amount of $\mathrm{ZnO}$ should not be too high.

\subsection{Bonding strength of the sesame protein-based adhesives}

The bonding strength of the USP/ZUSP adhesives is shown in Fig. 3. For the USP adhesive $(0 \% \mathrm{ZnO})$, the dry shear strength was $1.37 \mathrm{MPa}$. As the $\mathrm{ZnO}$ addition amount increased from 4 to $12 \%$, the dry shear strength increased from 2.11 MPa to $2.47 \mathrm{MPa}$, which increased from $54.0 \%$ to $80.3 \%$ compared with the USP adhesive. Upon further increasing the $\mathrm{ZnO}$ addition amount to $20 \%$, the dry shear strength decreased by $11.3 \%$ to $2.19 \mathrm{MPa}$ as compared to $12 \%$ for the ZUSP adhesive, but was still better than that of the USP adhesive. The wet shear strength

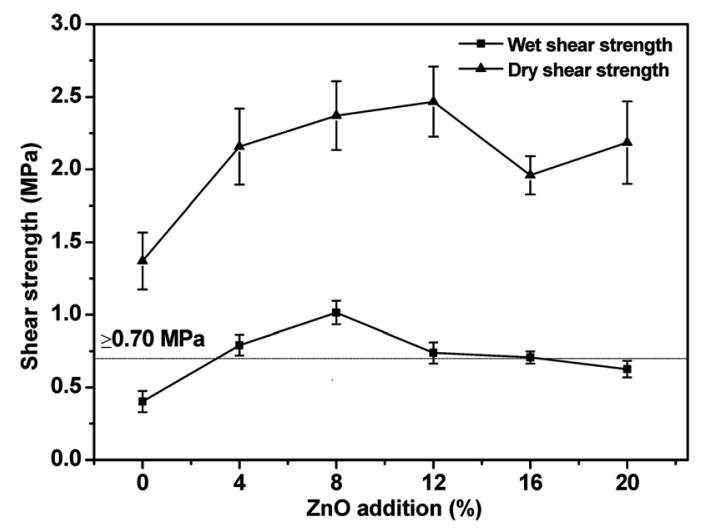

Fig. 3 Bonding strength of the USP/ZUSP adhesives. of the USP adhesive without $\mathrm{ZnO}$ was $0.40 \mathrm{MPa}$, which failed to achieve the required value for interior use $(\geq 0.70 \mathrm{MPa})$ in accordance with the China National Standard (GB/T 9843.32004). This behavior was attributed to one reason. Urea is a denaturing agent that can break the secondary structure of the sesame protein via the reaction between the oxygen and hydrogen atoms of urea and hydroxyl group of protein, which breaks down the hydrogen bonding of protein and forms a much small molecular chain protein; this leads to low water resistance of the USP adhesive. As shown in Fig. 1, the wet shear strength of the ZUSP adhesive with $4 \% \mathrm{ZnO}$ increased by $97.5 \%$ to $0.79 \mathrm{MPa}$, which reached the required value for interior use. By increasing the content of $\mathrm{ZnO}$ to $8 \%$, the wet shear strength of the ZUSP adhesive increased by $152.5 \%$ and reached a maximum value of 1.01 MPa. Upon further increasing the content of $\mathrm{ZnO}$ in the adhesives, the wet shear strength of the ZUSP adhesive with $20 \% \mathrm{ZnO}$ decreased by $37.6 \%$ to $0.63 \mathrm{MPa}$, which failed to achieve the required value for interior use as compared to $8 \%$ for the ZUSP adhesive. These behaviors were attributed to the following reasons. The chelation between zinc ion and $-\mathrm{NH}_{2}$ of the sesame protein might be the main reason for the improvement of the water resistance, which acted as a bridge to connect $\mathrm{ZnO}$ and protein like a network structure that prevented moisture intrusion. However, increase in the content of $\mathrm{ZnO}$ from 12 to $20 \%$ did not further enhance the wet shear strength of the ZUSP adhesive because of the excessive addition of ZnO. Therefore, the adhesive with a high solid content and low viscosity would lead to an over-penetration into the wood and low water resistance.

\subsection{FTIR spectroscopy measurement}

The FTIR spectra of the USP/ZUSP adhesives is shown in Fig. 4. The peaks observed at 3448 and $3352 \mathrm{~cm}^{-1}$ were attributed to the bending vibrations of free and bound $\mathrm{O}-\mathrm{H}$ and $\mathrm{N}-\mathrm{H}$ groups, which could form hydrogen bonds with the carbonyl group of the peptide linkage in the protein, respectively; this was confirmed by Mandal, A. B. by examining NMR experiments through the plots of changes in the chemical shifts as a function of temperature. ${ }^{30}$ The key absorption peaks of the USP/ZUSP adhesives were located at 1668 and $1624 \mathrm{~cm}^{-1}$, which were

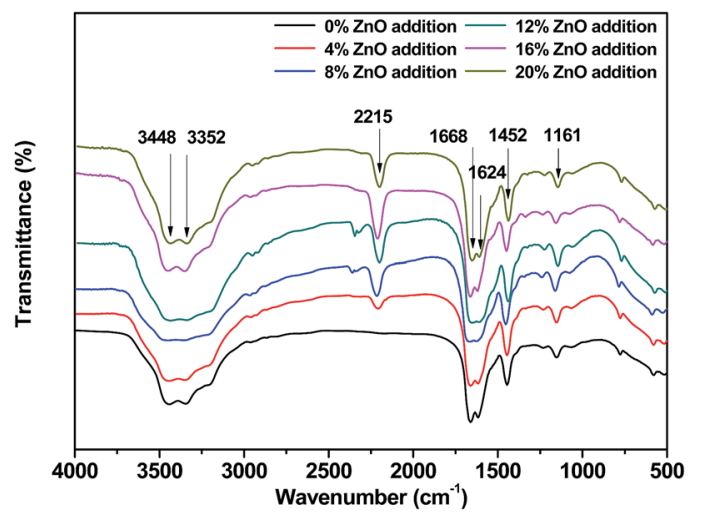

Fig. 4 FTIR spectra of the USP/ZUSP adhesives. 


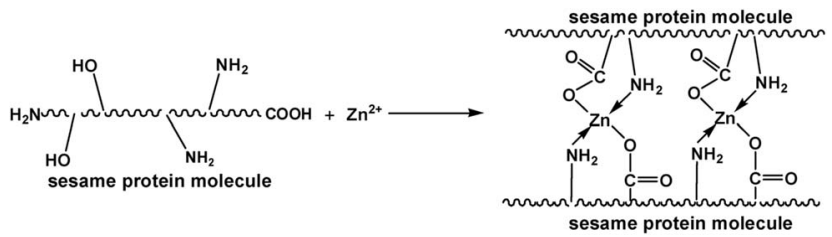

Fig. 5 The reaction process between the sesame protein and zinc oxide.

characteristic of amide I ( $\mathrm{C}=\mathrm{O}$ stretching) and amide II $(\mathrm{N}-\mathrm{H}$ bending), respectively. The bands corresponding to $-\mathrm{CH}$ bending and $-\mathrm{C}-\mathrm{O}-\mathrm{C}-$ stretching were 1452 and $1161 \mathrm{~cm}^{-1}$, respectively. However, a new absorption peak was observed at $2215 \mathrm{~cm}^{-1}$ in the FTIR spectra of the ZUSP adhesives, which could be attributed to the stretching vibration of the ring structure. The result showed that chelation reaction occurred between USP adhesive and ZnO. With the increase in the addition amount of $\mathrm{ZnO}$ from 0 to $20 \%$ in the adhesive, the peak observed at $2215 \mathrm{~cm}^{-1}$ gradually increased; this was due to the chelation reaction between $\mathrm{ZnO}$ and the $-\mathrm{NH}_{2}$ groups and $-\mathrm{COOH}$ groups of the sesame protein molecules. The sesame protein with two or more donor atoms (called polydents) could bind with a zinc ion within its electronic dents or claws by electron sharing between zinc ion and ligand $\left(-\mathrm{NH}_{2},-\mathrm{COOH}\right)$ and form a stable ring structure that improved the water resistance. The likely reaction mechanism is presented in Fig. 5 .

\subsection{TG analysis}

The thermogravimetric (TG) and derivative thermogravimetric (DTG) curves of the cured USP/ZUSP adhesives are shown in Fig. 6 . The thermal degradation process of the cured adhesives could be divided into four stages. In the first stage (I), the evaporation of residual moisture in the cured adhesives resulted in a small weight loss in the temperature range from $40^{\circ} \mathrm{C}$ to $145{ }^{\circ} \mathrm{C}$. The second stage (II) was related to the degradation of small molecules from sesame protein that were broken by urea and the breakage of unstable chemical bond in the temperature range from $145{ }^{\circ} \mathrm{C}$ to $250{ }^{\circ} \mathrm{C}$. Compared with the ZUSP adhesives, the USP adhesive showed a strong peak (derivative weight) in the second stage, and the residual weight of the USP adhesive in stage (II) was $49.2 \%$ that was less than that of the ZUSP adhesives with $4-20 \%$ added amount of $\mathrm{ZnO}(51.9,58.4,58.3$, 62.1 , and $66.3 \%$ ); this indicated that the process of urea modification produced more unstable chemical bonds and small molecules that presented a low water resistance. The third stage (III) was associated with the decomposition of the skeleton structure of the sesame protein in the temperature range from $250{ }^{\circ} \mathrm{C}$ to $370{ }^{\circ} \mathrm{C}$. During this stage, the protein backbone was absolutely decomposed and released all kinds of gases including $\mathrm{CO}_{2}, \mathrm{CO}$, and $\mathrm{NH}_{3} .{ }^{31}$ The peak (derivative weight) in stage (III) decreased with the increasing $\mathrm{ZnO}$ addition amount in ZUSP adhesives; this indicated that the main structure of the ZUSP adhesive changed as the $\mathrm{ZnO}$ addition amount increased. With an increase in the $\mathrm{ZnO}$ addition amount from 4 to $20 \%$ in the ZUSP adhesives, the final weight loss in stage (III) increased from $25.9 \%$ to $41.6 \%$. The fourth stage (IV) was attributed to the

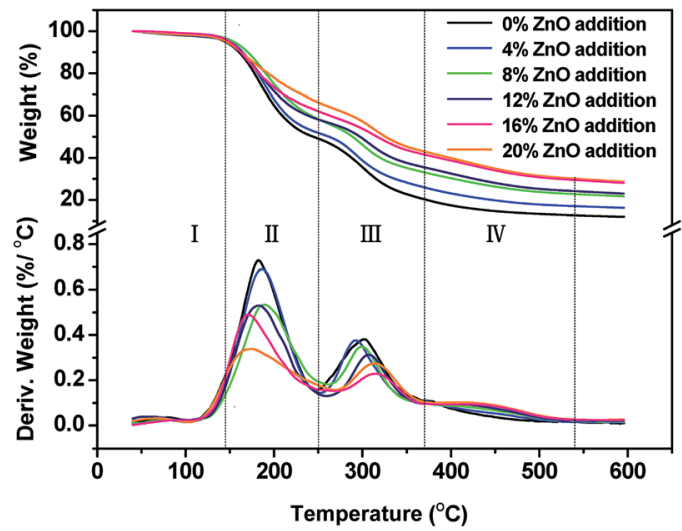

Fig. 6 The thermogravimetric (TG) and derivative thermogravimetric (DTG) curves of the USP/ZUSP adhesives.

decomposition of the cross-linking substance (the ring structure) between the $-\mathrm{NH}_{2}$ from the sesame protein and zinc ion with chelation in the temperature range from $370{ }^{\circ} \mathrm{C}$ to $540{ }^{\circ} \mathrm{C}$. Longtime urea modification could unfold sesame protein structure and expose more active groups such as $-\mathrm{NH}_{2}$ and $-\mathrm{COOH}$, which were responsible for the chelation reaction. The ring structure formed by the chelation reaction has high thermal stability that improves water resistance. In this stage, the thermal degradation behavior showed a significant difference with and without ZnO. The ZUSP adhesives had a weak peak (derivative weight) in this stage as compared to the USP adhesive, which had higher water resistance than the USP adhesive because of chelation. Finally, the residual weight of the adhesive with an increase in the $\mathrm{ZnO}$ addition amount from 0 to $20 \%$ was $11.9,16.3,21.8,23.0,28.1$, and $28.7 \%$, which indicated a better thermal stability of the ZUSP adhesive with the formation of nanomaterials.

\subsection{SEM analysis}

The fracture surface of the cured USP/ZUSP adhesives observed by scanning electron microscopy is presented in Fig. 7; the fracture surface of the cured USP adhesive $(0 \% \mathrm{ZnO})$ had a large number of holes and cracks and it also appeared very loose and disordered due to moisture vaporization during the hot-press process. Thus, the water resistance of the USP adhesive was low as compared to that of the ZUSP adhesives. After ZnO was introduced, the holes and cracks disappeared and the fractured surface of the cured ZUSP adhesives was more compact. These results showed that $\mathrm{ZnO}$ might fill the holes and cracks of the USP adhesive and cause the chelation reaction between itself and the USP adhesive that effectively prevented moisture penetration to improve the water resistance. In the ZUSP adhesive with $8 \%$ added amount of $\mathrm{ZnO}$, the fracture surface was ordered and rough such that it could easily combine with the rough surface of wood specimens, and this behavior resulted in high water resistance as compared to that of other ZUSP adhesives. With an increase in the $\mathrm{ZnO}$ addition amount to $20 \%$, the fracture surface of the cured adhesive was smoother than that of other cured ZUSP adhesives; this decreased the 

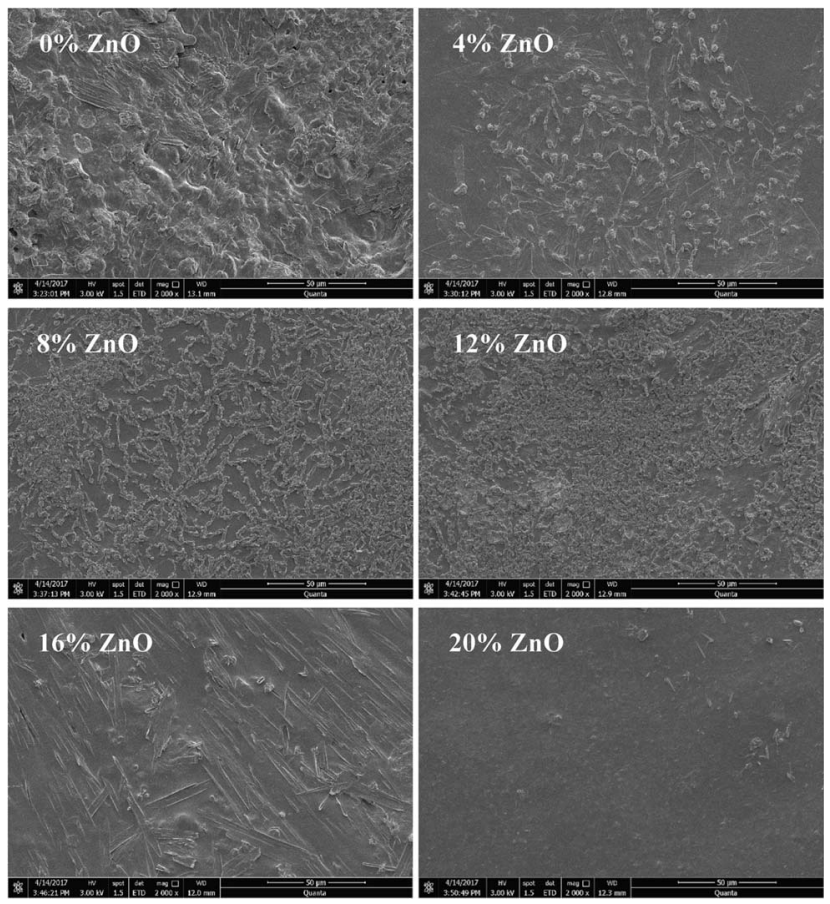

Fig. 7 SEM image of the fracture surface of the cured USP/ZUSP adhesives.

bonding capacity between adhesive and wood specimens, but it was still better than that of the USP adhesive. Therefore, $\mathrm{ZnO}$ improved the water resistance of the ZUSP adhesive.

\section{Conclusions}

The solid content of ZUSP adhesives gradually increased and the $\mathrm{pH}$ value maintained at around 9 when $\mathrm{ZnO}$ was added; the apparent viscosity of the ZUSP adhesives showed an increasing trend. In view of wet shear strength, the optimum addition amount of $\mathrm{ZnO}$ was $8 \%$. The wet shear strength of the ZUSP adhesives remarkably increased when $\mathrm{ZnO}$ was introduced. The wet shear strength of the ZUSP adhesive with $8 \% \mathrm{ZnO}$ increased by $152.5 \%$ as compared to that of the USP adhesive, which achieved the required value for interior use $(\geq 0.70 \mathrm{MPa})$ in accordance with the China National Standard (GB/T 9843.3-2004). Based on the FTIR spectra, the chelation reaction occurred between the USP adhesive and $\mathrm{ZnO}$ that might improve the water resistance. The TGA showed that the thermal stability of the ZUSP adhesives was better than that of the USP adhesive. The SEM images suggested that the fracture surface of the ZUSP adhesive was more compact as compared to that of the USP adhesive. Our research results suggest that the sesame protein extracted from sesame meal would be a new renewable material to be used as a low-cost and high-performance adhesive in the plywood industry.

\section{Conflicts of interest}

There are no conflicts to declare.

\section{Acknowledgements}

The authors are grateful for fund from Modern Agro-industry Technology Research System (CARS14-1-29).

\section{Notes and references}

1 J. Luo, J. Luo, Q. Gao and J. Li, Ind. Crops Prod., 2015, 63, 281286.

2 H. Li, C. Li, Q. Gao, S. Zhang and J. Li, Ind. Crops Prod., 2014, 59, 35-40.

3 P. Nordqvist, M. Lawther, E. Malmström and F. Khabbaz, Ind. Crops Prod., 2012, 38, 139-145.

4 A. Pizzi, J. Adhes. Sci. Technol., 2006, 20, 829-846.

5 F. Eslah, M. Jonoobi, M. Faezipour, M. Afsharpour and A. A. Enayati, Int. J. Adhes. Adhes., 2016, 71, 48-54.

6 H. Lei, Z. Wu, M. Cao and G. Du, Polymers, 2016, 8, 256.

7 G. Qi, N. Li, D. Wang and X. S. Sun, J. Am. Oil Chem. Soc., 2016, 93, 1509-1517.

8 J. Li, X. Li, J. Li and Q. Gao, RSC Adv., 2015, 5, 80136-80141.

9 H. N. Cheng, C. Ford, M. K. Dowd and Z. He, Ind. Crops Prod., 2016, 85, 324-330.

10 H. N. Cheng, C. Ford, M. K. Dowd and Z. He, Int. J. Adhes. Adhes., 2016, 68, 156-160.

11 Z. He, D. C. Chapital and H. N. Cheng, J. Appl. Polym. Sci., 2016, 133, 43637-43643.

12 H. Liu, C. Li and X. S. Sun, Ind. Crops Prod., 2015, 74, 577584.

13 N. S. Hettiarachchy, U. Kalapathy and D. J. Myers, J. Am. Oil Chem. Soc., 1995, 72, 1461-1464.

14 W. Huang and X. Sun, J. Am. Oil Chem. Soc., 2000, 77, 705708.

15 W. Huang and X. Sun, J. Am. Oil Chem. Soc., 2000, 77, 101104.

16 J. Luo, J. Luo, C. Yuan, W. Zhang, J. Li, Q. Gao and H. Chen, RSC Adv., 2015, 5, 100849-100855.

17 G. Qi, N. Li, D. Wang and X. S. Sun, Ind. Crops Prod., 2013, 46, 165-172.

18 J. Luo, X. Li, H. Zhang, Q. Gao and J. Li, Int. J. Adhes. Adhes., 2016, 71, 99-104.

19 Z. Zhong and X. S. Sun, J. Biobased Mater. Bioenergy, 2007, 1, 380-387.

20 R. Nilo Rivas, J. E. Dench and J. C. Caygill, J. Sci. Food Agric., 1981, 32, 565-571.

21 A. B. Mandal, S. Ray, A. M. Biswas and S. P. Moulik, J. Phys. Chem., 1980, 84, 856-859.

22 A. B. Mandal, D. Mukherjee and D. Ramaswamy, Leather Sci., 1983, 28, 283-288.

23 A. B. Mandal, D. Ramaswamy, D. K. Das and M. Santapp, Colloid Polym. Sci., 1982, 260, 702-707.

24 A. B. Mandal, M. Kanthimathi, K. Govindaraju and D. Ramaswamy, J. Soc. Leather Technol. Chem., 1983, 67, 147-158.

25 C. Rose and A. B. Mandal, Int. J. Biol. Macromol., 1996, 18, 41-53.

26 X. Sun and B. Ke, J. Am. Oil Chem. Soc., 1999, 76, 977-980. 27 S. L. Vieira, Rev. Bras. Cienc. Avic., 2008, 10, 73-79. 
28 E. Onsaard, P. Pomsamud and P. Audtum, As. J. Food Ag-Ind., 2013, 3, 420-431.

29 Q. Gao, J. Li, S. Q. Shi, K. Liang and X. Zhang, BioResources, 2012, 7, 5622-5633.
30 A. B. Mandal and R. Jayakumar, J. Chem. Soc., Faraday Trans., 1994, 90, 161-165.

31 S. N. Das, M. Routray and P. L. Nayak, Polym.-Plast. Technol. Eng., 2008, 47, 576-582. 